\title{
Effect of an Extract of Artemisia vulgaris L. (Mugwort) on the in vitro Labeling of Red Blood Cells and Plasma Proteins with Technetium-99m
}

\author{
Danielle Amorim Terra ${ }^{1 *}$, Lúcia de Fátima Amorim ${ }^{2}$, Maria Tereza Jansen de Almeida \\ Catanho $^{3}$, Adenilson de Souza da Fonseca ${ }^{4}$, Sebastião David Santos-Filho ${ }^{4}$, José Brandão- \\ Neto $^{1}$, Aldo da Cunha Medeiros ${ }^{1}$ and Mario Bernardo-Filho ${ }^{4}$ \\ ${ }^{1}$ Programa de Pós-Graduação em Ciências da Saúde; Centro de Ciências da Saúde; Universidade Federal do Rio \\ Grande do Norte; Avenida Ganeral Gustavo Cordeiro de Farias, s/n; 59010-180; dan.amorim@ gmail.com; Natal - \\ RN - Brasil. ${ }^{2}$ Departamento de Biofísica; Centro de Biociências; Universidade Federal do Rio Grande do Norte; \\ Avenida Ganeral Gustavo Cordeiro de Farias, s/n; 59010-180; Natal - RN - Brasil. ${ }^{3}$ Departamento de Biofísica e \\ Radiobiologia; Universidade Federal de Pernambuco; Avenida Prof. Moraes Rego; CDU; 50670-901; Recife - PE - \\ Brasil. ${ }^{4}$ Departamento de Biofísica e Biometria; Instituto de Biologia Roberto Alcântara Gomes; Universidade do \\ Estado do Rio de Janeiro; Avenida 28 de Setembro, 87; 200551-030; Rio de Janeiro - RJ - Brasil
}

\begin{abstract}
The aim of this work was to evaluate the effect of an extract of the Artemisia vulgaris L. (mugwort) on the labeling of blood constituents with technetium-99m $(99 \mathrm{mTc})$. Blood samples from Wistar rats were incubated with a mugwort extract and the radiolabeling of blood constituents was carried out. Plasma and blood cells were separated by centrifugation. Aliquots of plasma and blood cells were also precipitated with trichloroacetic acid and centrifuged to isolate soluble and insoluble fractions of plasma and blood cells. Radioactivity in each fraction was counted and the percentages of radioactivity (\%ATI) was calculated. Mugwort extract decreased significantly ( $p<0.05)$ the \%ATI on the blood compartments and on the blood cells proteins (insoluble fraction). The analysis of the results indicates that the extract could have substances that could interfere on the transport of stannous through the erythrocyte membrane alterating the labeling of blood cells with $99 \mathrm{mTc}$.
\end{abstract}

Key words: Artemisia vulgaris L., Technetium-99m, Blood constituents, labeling

\section{INTRODUCTION}

Artemisia vulgaris L. (mugwort), belonging to the family of Asteraceae, is a perennial weed growing wild and abundantly in temperate and coldtemperature zones of the word (Cui, 1989). In Traditional Chinese Medicine, mugwort has been used as an analgesic agent and in conjunction with acupuncture therapy (Yoshikawa et al., 1996), to treat the neonatal jaundice (Fok, 2001), gastric ulcers (Repetto et al., 2002), hepatitis (Tan et al., 1999) and convulsive crisis (Hickey et al, 2004).

Mugwort leaves and stem are used medicinally as a bitter digestive tonic, uterine stimulant and antirheumatic (Hickey et al., 2004). Some reports have revealed that mugwort is a potent immunomodulatory (Schmid-Grendelmeier et al., 2003), antihypertensive (Tigno et al., 2000), antinflammatory (Tigno and Gumila, 2000),

Author for correspondence 
antioxidant (Luo et al., 2007) and hepatoprotective agent (Gilani et al., 2005).

Antitumoral activity has been reported to artemisic acid and artemisinin B extracted from mugwort (Sun et al., 1992). Insect repellent and fumigant activity has been found in essential oils from mugwort (Wang et al., 2006). The insecticidal activity of essential oils from mugwort has been evaluated on Aedes aegipti (Chantraine et al., 1998). In addition, anti-viral activity has also been described to extracts of this plant (Tan et al., 1998).

Phytochemical studies have identified more than 20 flavonoids in mugwort extracts (Lee, 1998). Some flavonoids as well as acetylenes, coumarins, sesquiterpene lactones, and volatile oil components have previously been reported from mugwort (Marco et al., 1990). The most abundant compounds were eriodicyol and luteolin (Lee, 1998).

Despite the beneficial effects described by users, the indiscriminate use of this and other plants and infusions without medical advice/criteria can be dangerous. Several cases of biological effects of medicinal plants have been reported and drug interactions and side effects of these products are not completely known (Rotblatt and Ziment, 2002).

Molecules or cells labeled with technetium-99m $(99 \mathrm{mTc})$ are radiopharmaceuticals used in nuclear medicine procedures as imaging agents (Saha, 2004; Bernardo-Filho et al., 2005).

The labeling of red blood cells with $99 \mathrm{mTc}$ is a technique based on the reducing agent (stannous chloride) action on pertechnetate ion (BernardoFilho et al., 1983; Sampson, 1996, Saha, 2004).

Several factors can influence the labeling of blood constituents with $99 \mathrm{mTc}$ (Bernardo-Filho et al., 2005). Some investigators have reported that phytotherapeutic agents could alter the labeling of blood constituents with $99 \mathrm{mTc}$ (Oliveira et al., 2002; Santos-Filho et al., 2004; Abreu et al., 2006). The aim of this study was to evaluate the influence of mugwort extract on the labeling of blood constituents with $99 \mathrm{mTc}$.

\section{MATERIALS AND METHODS}

The protocol was approved by the Ethical Committee of animal care in experiments of the Universidade Federal de Pernambuco.
Mugwort was collected and a specimen was identified by Professor Iracema Loiola of the Universidade Federal do Rio Grande do Norte, Rio Grande do Norte, Brazil. A voucher specimen was deposited in the Universidade Federal do Rio Grande do Norte, Rio Grande do Norte, Brazil, and has received the number UFRN-3872.

Wistar male rats (3-4 months, $300 \pm 50 \mathrm{~g})$ were maintained in a controlled environment and allowed free access to water and food and ambient temperature was kept at $25 \pm 2{ }^{\circ} \mathrm{C}$.

In the preparation of the mugwort extract, $100 \mathrm{ml}$ of boiled saline $(0.9 \% \mathrm{NaCl})$ solution was added to $1 \mathrm{~g}$ of leaves. After that, the preparation was keeped in infusion for $5 \mathrm{~min}$. The preparation was filtered and the supernatant was considered to be $10 \mathrm{mg} / \mathrm{ml}$. Stannous chloride $\left(\mathrm{SnCl}_{2}\right)$ was purchased from Sigma Chemical Co., St Louis, USA.

Heparinized whole blood was withdrawn from Wistar rats. Blood samples $(500 \mu \mathrm{l})$ were incubated with $100 \mu \mathrm{l}$ of mugwort extract at different concentrations $(0.62,1.25,2.50,5.00$ and 10.00 $\mathrm{mg} / \mathrm{ml}$ ) or with saline solution alone, as control, for $1 \mathrm{~h}$ (room temperature). Then, $0.5 \mathrm{ml}$ of a stannous chloride solution $(1.2 \mu \mathrm{g} / \mathrm{ml})$ freshly prepared was added and the incubation continued for another 1 hour. After that, $99 \mathrm{mTc}(0.1 \mathrm{ml}$; $3.7 \mathrm{MBq}$ ), in the form of sodium pertechnetate $\left(99 \mathrm{mTcO}_{4} \mathrm{Na}\right)$ recently milked from a 99Mo/99mTc generator (Instituto de Pesquisas Energéticas e Nucleares, Comissão Nacional de Energia Nuclear, São Paulo, Brazil) was added and the incubation continued for $10 \mathrm{~min}$, as previously described (Bernardo-Filho et al., 1983). These blood samples were centrifuged (1500 rpm, 5 min) to plasma and blood cells separation. Aliquots of plasma and blood cells were also precipitated in 5\% trichloroacetic acid and centrifuged (1500 rpm, $5 \mathrm{~min}$, clinical centrifuge) to isolate soluble and insoluble fractions. The radioactivity in each fractions was counted in a well counter (Automatic Gamma Counter, C5002, Packard, USA). The percentage of radioactivity (\%ATI) in each fraction was calculated

The data are reported as media \pm standard deviation of \%ATI. Statistical analysis was performed by Kruskal-Wallis and Mann Whitney test. A $p<0.05$ was considered as statistical significance. 


\section{RESULTS}

Table 1 shows the distribution of radioactivity in cellular and plasma compartments from blood incubated with mugwort extract. The results indicate that there was a significant $(p<0.05)$ decrease in the radioactivity uptake by cellular compartment in the presence of mugwort extract when compared with the control (blood samples incubated with saline solution).

Table 2 shows the fixation of radioactivity on soluble and insoluble fractions of blood cells from blood samples incubated with mugwort extract. The data indicate that there was a significant $(p<0.05)$ reduction in the radioactivity fixation on insoluble fraction of blood cells.

Table 3 shows the fixation of radioactivity on soluble and insoluble fractions of plasma proteins from blood samples incubated with mugwort extract. The results indicate that there was no significant $(p>0.05)$ alteration of radioactivity fixation on the fractions of plasma when compared with control.

Table 1 - Effect of the mugwort extract on the distribution of the radioactivity between cellular and plasma compartments

\begin{tabular}{lcc}
\hline $\begin{array}{l}\text { Mugwort } \\
(\mathbf{m g} / \mathbf{m L})\end{array}$ & BC & \%ATI \\
\hline 0.0 (control) & $98.32 \pm 0.52$ & P \\
0.62 & $92.58 \pm 1,23$ & $1.68 \pm 0.52$ \\
$1.25^{*}$ & $81.50 \pm 1.67$ & $7.42 \pm 1.23$ \\
$2.50^{*}$ & $73.29 \pm 3.95$ & $18.50 \pm 1.57$ \\
$5.00^{*}$ & $70.42 \pm 3.47$ & $26.71 \pm 3.95$ \\
$10.00^{*}$ & $68.01 \pm 3.73$ & $29.58 \pm 3.47$ \\
\hline
\end{tabular}

Blood samples from Wistar rats were incubated with mugwort extract for 1 hour. Then, radiolabeling procedure of blood constituents was carried out. The samples were centrifuged to plasma (P) and blood cells (BC) separation. Radioactivity in each fraction was counted and the \%ATI was calculated. $(*) p<0.05$ when compared with control.

Table 2 - Effect of mugwort extract on the fixation of radioactivity on fractions of blood cells

\begin{tabular}{lcc}
\hline $\begin{array}{l}\text { Mugwort } \\
(\mathbf{m g} / \mathbf{m L})\end{array}$ & IF-BC & \%ATI \\
\hline 0.0 (control) & $95.46 \pm 1.78$ & SF-BC \\
$0.62 *$ & $83.66 \pm 2.95$ & $4.54 \pm 1.78$ \\
$1.25^{*}$ & $76.44 \pm 2.46$ & $16.34 \pm 2.95$ \\
$2.50^{*}$ & $69.76 \pm 4.46$ & $23.56 \pm 2.46$ \\
$5.00^{*}$ & $72.92 \pm 0.81$ & $30.24 \pm 4.46$ \\
$10.00^{*}$ & $67.83 \pm 2.38$ & $27.08 \pm 0.81$ \\
\hline
\end{tabular}

Blood samples from Wistar rats were incubated with mugwort extract and labeling of blood constituents with $99 \mathrm{mTc}$ was performed. Insoluble (IF) and soluble (SF) fractions from blood cells (BC) were isolated, radioactivity was counted and the percentage of the radioactivity (\%ATI) was calculated. $(*) p<0.05$ when compared with control.

\section{DISCUSSION}

Some authors have been reported that natural and synthetic drugs could alter the labeling of blood constituents with $99 \mathrm{mTc}$ (Frydman et al., 2004; Abreu et al., 2006; Fonseca et al., 2007). The labeling of blood constituents would decrease due to the action of drugs that could (1) bind at the same sites of $99 \mathrm{mTc}$ on the blood constituents, (2) directly inhibit (chelating action) of the stannous and pertechnetate ions, (3) oxidize or generate free radicals that could oxidize the stannous ion, and (4) alter the plasma membrane structure or modify the transport systems of stannous and pertechnetate ions into cells. 
Table 3 - Effect of mugwort extract on the fixation of radioactivity on fractions of plasma

\begin{tabular}{lccc}
\hline Mugwort $\mathbf{~ m g / m L ) ~}$ & IF-P & \%ATI & SF-P \\
\hline 0.0 (control) & $75.44 \pm 1.91$ & $24.56 \pm 1.91$ \\
0.62 & $73.03 \pm 2.64$ & $26.97 \pm 2.64$ \\
1.25 & $76.84 \pm 0.87$ & $23.16 \pm 0.87$ \\
2.50 & $69.39 \pm 3.37$ & & $30.61 \pm 3.37$ \\
5.00 & $75.53 \pm 3.01$ & & $24.47 \pm 3.01$ \\
10.00 & $72.26 \pm 5.19$ & $27.74 \pm 5.19$ \\
\hline
\end{tabular}

Blood samples from Wistar rats were incubated with mugwort extract and labeling of blood constituents with $99 \mathrm{mTc}$ was performed. Insoluble (IF) and soluble (SF) fractions from plasma (P) were isolated, radioactivity was counted and the percentage of the radioactivity (\%ATI) was calculated.

Luo et al. (2007) have demonstrated that aqueous and hidroalcoholic extracts of mugwort leaves present anti-microbial activity. If this activity was related with actions on the plasma membrane, this finding could be also related with effects on the membrane of red blood cells. A possible modication on the erythrocyte membrane could alter its structure, decreasing and/or blocking the transport of stannous and pertechnetate ions into blood cells. In consequence the labeling efficiency of blood constituents with $99 \mathrm{mTc}$ would be decreased.

Authors using mugwort have described that flavonoids have decreased the spasmolytic activity in experimental models (Lozoya et al., 1994) and have antioxidant and radical-scavenging properties (Miyake and Shibamoto, 1997). These findings can also aid to understand the effect of the extract on the labeling of blood constituents (Table 1 and 2).

Other data have indicated inhibition of acetylcholine release in neuromuscular junctions by calcium-antagonistic action of quercetin decreasing the inward calcium membrane current leading to a decrease of smooth muscle contractile force (Losoya et al., 1994; Re et al., 1999; Morales et al., 1994) and depression of myocardial inotropism (Conde Garcia et al., 2003). As calcium and stannous ions are very similar (Gutfilen et al, 1992), these described actions of the mugwort extract on the calcium flow through the membrane could justify the decrease of the radiolabeling of blood cells with $99 \mathrm{mTc}$.

The analysis of the results indicates that the extract could have substances that could interfere on the transport of stannous ions through the erythrocyte membrane. In consequence, it would be expected that the labeling of blood cells with $99 \mathrm{mTc}$ would be altered. Moreover, morphological experiments are ongoing to try to verify the action of this extract on the shape of the red blood cells.

\section{RESUMO}

O objetivo desse trabalho foi avaliar o efeito da Artemisia vulgaris L.(artemisa) na marcação dos constituintes sangüíneos com tecnécio-99m $(99 \mathrm{mTc})$. Amostras de sangue obtidas de ratos Wistar foram incubadas com um extrato de artemisa e o processo de radiomarcação dos constituintes sangüíneos foi realizado. Plasma e células sanguíneas foram isoladas por centrifugação. Alíquotas de plasma e células sangüíneas foram também precipitadas com ácido tricloroacético para isolamento de frações solúvel e insolúvel. A radiatividade em cada fração foi contada e as porcentagens de radioatividade (\%ATI) foram calculadas. O extrato de artemisa diminuiu significantemente $(\mathrm{p}<0,05)$ a \%ATI nas células sanguíneas e nas proteínas celulares. A análise dos resultados indicou que o extrato de artemisa apresentaria substâncias que interferir no transporte de íons estanoso e/ou pertecnetato através da membrana do eritrócito alterando a marcação das células sangúineas com $99 \mathrm{mTc}$.

\section{REFERENCES}

Abreu, P. R.; Almeida, M. C.; Bernardo, R. M.; Bernardo, L. C.; Brito, L. C.; Garcia, E. A.; Fonseca, A. S. and Bernardo-Filho, M. (2006), Guava extract (Psidium guajava) alters the labelling of blood constituents with technetium-99m. J. Zhejiang Univ. Sci. B., 7, 429-435. 
Bernardo-Filho, M.; Moura, I.N.S. and Boasquevisque, E.M. (1983), 99m-technetium-labelled red blood cells "in vitro". Braz. Arch. Biol. Tecnol., 26, 455-461.

Bernardo Filho, M.; Santos-Filho, S. D.; Moura, E. G.; Maiworm, A. I.; Orlando, M. M. C.; Penas, M. E.; Cardoso, V. N.; Bernardo, L. C. and Brito, L. C. (2005), Drug interaction with radiopharmaceutical: A review. Braz. Arch. Biol. Technol., 48, 12-27.

Callahan, R. J. and Rabito, C. A. (1990), Radiolabelling of erythrocytes with technetium-99m: role of band-3 protein in the transport of pertechnetate across the cell membrane. J. Nucl. Med., 31, 2004-2010.

Conde Garcia, E. A.; Nascimento, V. T. and Santos, A. B. S. (2003), Inotropic effects of extracts of Psidium guajava L. (guava) leaves on the guinea pig atrium. Braz. J. Med. Biol. Res., 36, 661-668.

Cui, S. D. (1989), Codex of Chinese Traditional Medicine. Hei Long-jiang Science and Technology Press, Ha Er-bin.

Fok, T. F. (2001), Neonatal Jaundice - Traditional Chinese Medicine Approach. J. Perinatol., 21, 98100 .

Fonseca, A. S.; Frydman, J. N.; Rocha, V. C. and Bernardo-Filho, M. (2007), Acetylsalicylic acid decreases the labeling of blood constituents with technetium-99m. Acta Biol. Hung., 58, 187-198.

Frydman, J.N.G.; Oliveira, M.B.N.; Santos, A.E.O.; Fonseca, A.S.; Santos, R. and Bernardo-Filho, M. (2004), Influence of methylxanthines on the labelling of blood elements with ${ }^{99 \mathrm{~m}}$ Technetium. Pakistan J. Biol. Sci., 4, 521-524.

Gilani, A. H.; Yaeesh, S.; Jamal, Q. and Ghayur, M. N. (2005), Hepatoprotective activity of aqueousmethanol extract of Artemisia vulgaris. Phytother. Res., 19, 170-172.

Gutfilen, B.; Boasquevisque, E. and Bernardo-Filho, M. (1992), Calcium channel blockers: interference on red blood cells and plasma proteins labeling with 99mTc. Rev. Española Med. Nucl., 11, 195-199.

Lee, S. J. (1998), Estrogenic Flavonoids from Artemisia vulgaris L. J. Agric. Food Chem., 46, 3325-3329.

Lozoya, X.; Meckes, M.; Aboud-Zaid, M.; Tortoriello, J.; Nozolillo, C. and Arnason, J.T. (1994), Quercetine glycosides in Psidium guajava L. leaves and determination of a spasmolytic principle. Arch. Med. Res., 25, 11-15.

Luo, H.; Lin, S.; Ren, F.; Wu, L.; Chen, L. and Sun, Y. (2007), Antioxidant and microbial capacity of Chinese medicinal herb extracts in raw sheep meat. $J$. Food Prot., 70, 14440-14445.

Marco, T. J. and Barbera, O. (1990), Natural Products from the genus Artemisia L. In Studies in Natural Products Chemistry. Atta-ur-Rahman, Elsevier: Amsterdam.
Miyake, T. and Shibamoto, T. (1997), Antioxidative activities of natural compounds foundin plants. $J$. Agric. Food Chem., 45, 1819-1822.

Morales, M.A.; Trotoriello, J.; Meckes, M.; Paz, D. and Lozoya, X. (1994), Calcium-antagonist effect of quercetin and its relation with the spasmolytic properties of Psidium guajava L. Arch. Med. Res., 25, 17-21.

Oliveira, J. F.; Avila, A. S.; Braga, A. C.; de Oliveira, M. B.; Boasquevisque, E. M.; Jales, R. L.; Cardoso, V. N. and Bernardo-Filho, M. (2002), Effect of extract of medicinal plants on the labeling of blood elements with Technetium-99m and on the morphology of red blood cells: I--a study with Paullinia cupana. Fitoterapia, 73, 305-312.

Re, L.; Barocci, S.; Capitani, C.; Vivani, C.; Ricci, M.; Rinaldi, L.; Paolucci, G.; Scarpantonio, A.; LeonFernandez, O. S. and Morales, M. A. (1999), Effects of some natural extracts on the acetylcholine release at the mouse neuromuscular junction. Pharmacol. Res., 39, 239-245.

Repetto, M. G. and Llesuy, S. F. (2002), Antioxidant properties of natural compounds used in popular medicine for gastric ulcers. Braz. J. Med. Biol. Res., 35, 523-534.

Rotblatt, M. and Ziment, I. (2002), Evidence-Based Herbal Medicine. Philadelphia: Hanley and Belfus.

Saha, G. B. (2004), Fundamentals of Nuclear Pharmacy. Springer-Verlag, New York.

Sampson, C. B. (1996), Complications and difficulties in radiolabeling blood cells: A review. Nucl. Med. Commun., 17, 648-658.

Santos-Filho, S. D. and Bernardo-Filho, M. (2005), Effect of Hypericum perforatum extract on in vitro labelling of blood elements with technetium-99m and on biodisponibility of sodium pertechnetate in Wistar rats. Acta Cir. Bras., 20, 76-80.

Schmid-Grendelmeier, P.; Holzmann, D.; Himly, M.; Weichel, M.; Tresch, S.; Ruckert, B.; Menz, G.; Ferreira, F.; Blaser, K.; Wuthrich, B. and Crameri, R. (2003), Native Art v 1 and recombinant Art v 1 are able to induce humoral and $\mathrm{T}$ cell-mediated in vitro and in vivo responses in mugwort allergy. J. Allergy Clin. Immunol., 111, 1328-1336.

Sun, W. C.; Han, J. X.; Yang, W. Y.; Deng, D. A. and Yue, X. F. (1992), Antitumor activities of 4 derivatives of artemisic acid and artemisinin B in vitro, Acta Pharmacol. Sin., 13, 541-543.

Tan, R. X.; Lu, H.; Wolfender, J L.; Yu, T.T.; Zheng, W. F.; Yang, L.; Gafner, S. and Hostettmann, K. (1999), Mono- and sesquiterpenes and antifungal constituents from Artemisia species. Planta Med., 65, 64-67.

Tigno, X. T.; de Guzman, F. and Flora, A. M. (2000), Phytochemical analysis and hemodynamic actions of Artemisia vulgaris L. Clin. Hemorheol. Microcirc., 23, 167-175. 
Tigno, X. T. and Gumila E. (2000), In vivo microvascular actions of Artemisia vulgaris L. in a model of ischemia-reperfusion injury in the rat intestinal mesentery. Clin. Hemorheol. Microcirc., 23, 159-165.

Wang, J.; Zhu, F.; Zhou, X. M.; Iu, C. Y. and Lei, C. L. (2006), Repellent and fumigant activity of essential oil from Artemisia vulgaris to Tribolium castaneum (Herbst) (Coleoptera: Tenebrionidae). J. Stored Prod. Res., 42, 339-347.
Yoshikawa, M.; Shimada, H.; Matsuda, H.; Yamahara, J. and Murakami, N. (1996), Bioactive constituents of Chinese natural medicines I. Chem. Pharm. Bull., 44, 1656-1662.

Received: July 31, 2007; Revised: August 08, 2007; Accepted: Sepember 11, 2007. 